\title{
Interaction of Four Antagonistic Fungi with Botrytis aclada in Dead Onion Leaves: A Comparative Microscopic and Ultrastructural Study
}

\author{
J. Köhl, R. R. Bélanger, and N. J. Fokkema
}

First and third authors: DLO Research Institute for Plant Protection (IPO-DLO), P.O. Box 9060, 6700 GW Wageningen, the Netherlands; second author: Departement de Phytologie-FSAA, Centre de Recherche en Horticulture, Universite Laval, Quebec, G1K 7P4 Canada. Accepted for publication 5 March 1997.

\begin{abstract}
Köhl, J., Bélanger, R. R., and Fokkema, N. J. 1997. Interaction of four antagonistic fungi with Botrytis aclada in dead onion leaves: A comparative microscopic and ultrastructural study. Phytopathology 87:634-642.

The colonization of dead onion leaves by Botrytis aclada and the fungal antagonists Aureobasidium pullulans, Chaetomium globosum, Gliocladium catenulatum, and Ulocladium atrum and the interactions between B. aclada and each of the four antagonists were studied at the microscopic and ultrastructural level. This approach was used in an attempt to understand the colonization pattern of these fungi and the nature of the biocontrol activity of the antagonists that have shown a potential to suppress spore production of Botrytis spp. on necrotic plant tissues. When applied alone, B. aclada and U. atrum were found throughout the leaf tissues in high densities after an incubation period of 6 days at $18^{\circ} \mathrm{C}$ in a moist chamber. C. globosum and G. catenulatum colonized only the outer portions of the leaf, whereas A. pullulans appeared to be concen-
\end{abstract}

ABSTRACT

Botrytis spp. cause severe damage on a wide range of crops. Biological control of necrotrophic pathogens such as Botrytis spp. can be achieved by the suppression of spore production by the pathogen on necrotic plant tissues, resulting in a lower density of initial or secondary inoculum of the pathogen within the crop $(12,19,25)$. This may result in a delay of the start or progression of epidemics incited by the pathogen $(17,19,26)$.

In a previous screening program, Chaetomium globosum Kunze:Fr., Gliocladium catenulatum Gilman \& E. Abbott, and Ulocladium atrum $\mathrm{G}$. Preuss efficiently suppressed sporulation of B. aclada Fresen. and B. cinerea Pers.:Fr. on dead onion leaves under laboratory conditions, whereas Aureobasidium pullulans (de Bary) G. Arnaud was moderately effective (21). Antagonism of $A$. pullulans, $C$. globosum, and $U$. atrum was not reduced when leaf wetness periods were interrupted to simulate field conditions, whereas $G$. catenulatum was sensitive to dry conditions. The four isolates were tested in a series of nine small-scale field experiments under a broad range of environmental conditions (20). $U$. atrum consistently reduced sporulation of $B$. cinerea by more than $90 \%$ in all experiments. Applications of $G$. catenulatum and $C$. globosum caused significant sporulation reduction in one and three experiments, respectively. A. pullulans did not reduce sporulation of $B$. cinerea under the experimental conditions.

Very little is known about the mechanisms involved in the antagonism by these four organisms. A better understanding of the mechanisms is essential for the further exploitation of the antago-

Corresponding author: J. Köhl; E-mail address: j.kohl@ipo.dlo.nl

Publication no. P-1997-0421-01R

(C) 1997 The American Phytopathological Society trated in the leaf stomata. When pathogen and antagonists were applied together, ultrastructural observations revealed that cells of B. aclada were plasmolyzed in the presence of $G$. catenulatum, suggesting a reaction to antifungal molecules. Antibiosis also seemed to be involved, albeit to a lesser extent, in the antagonistic interactions between $B$. aclada and A. pullulans or C. globosum. No evidence of direct parasitism was recorded. On the other hand, $U$. atrum appeared to completely exclude B. aclada from dead onion tissues when both fungi competed for the substrate. Ultrastructural observations of the in vitro interaction between the two fungi did not reveal parasitism or antibiosis by either fungus. Based on previous records of its biocontrol potential and observations of its colonizing properties, it appears that $U$. atrum can compete for and utilize necrotic tissues rapidly and extensively, thus, excluding competitors without any other antagonistic action.

Additional keywords: biological control, cell damage.

nists in necrotic tissues of various crops under different environmental conditions. Population densities of the antagonists in the necrotic substrates necessary to achieve sufficient control levels and the timing of antagonist applications may depend on the underlying mechanisms. Furthermore, necrotic tissues from different crops may have a differential effect on the expression of such mechanisms.

The objective of our study was to elucidate the mechanisms involved in the antagonistic interactions between a Botrytis sp. and these four antagonists during the saprophytic colonization of necrotic plant tissues. Parasitism, antibiosis, and nutrient competition may be components of the antagonistic activity (27). Whereas in vitro tests can be useful to determine enzymatic or antibiotic activity of biocontrol agents, they cannot determine how and if these mechanisms take place when the organisms are interacting on their natural substrate. We used microscopic and ultrastructural studies to analyze and compare the behavior of the four antagonists as they developed on dead onion leaves. This is, to our knowledge, the first report of ultrastructural observations on the interference between a saprophytically growing pathogen and antagonists in dead plant tissues.

\section{MATERIALS AND METHODS}

Fungal material. B. aclada (synanamorph B. allii Munn), causing onion neck rot, was chosen as the model pathogen and was isolated from onion seed. The antagonists (with isolate number) A. pullulans (490), C. globosum (256), and U. atrum (385) were isolated from necrotic leaf tips of field-grown onions (21). G. catenulatum (162), originating from red clover root, was provided by P. Lüth, Prophyta Biologischer Pflanzenschutz GmbH, Malchow, Germany. 
Onion leaves. Symptomless green leaves were removed from 12-week-old field-grown plants of onion cv. Hyton, dried for several days at $60^{\circ} \mathrm{C}$, and stored in paper bags at room temperature in the dark (21). Dried leaves were cut into $2-\mathrm{cm}$ segments, sealed in plastic bags, and sterilized by gamma radiation of $4 \mathrm{Mrad}$.

Conidial suspensions. All fungi were cultured in petri dishes on oatmeal agar (20 g of oatmeal, $15 \mathrm{~g}$ of agar, and 1,000 $\mathrm{ml}$ of tap water), except $A$. pullulans, which was grown on basal yeast agar (10 g of bacteriological peptone, $20 \mathrm{~g}$ of sucrose, $1 \mathrm{~g}$ of yeast extract, $20 \mathrm{~g}$ of agar, and 1,000 $\mathrm{ml}$ of tap water). Cultures were incubated for 3 days for A. pullulans, 14 days for C. globosum and $G$. catenulatum, and 21 days for $U$. atrum. To obtain spore suspensions, cultures were flooded with sterile tap water containing $0.01 \%$ Tween 80 . After gently rubbing with a rubber spatula to remove spores from fungal cultures, suspensions were filtered through a sterile nylon gauze with a mesh of $200 \mu \mathrm{m}$. Concentrations of spore suspensions were determined with a haemocytometer and adjusted with sterile tap water containing $0.01 \%$ Tween 80 to $1 \times 10^{6}$ spores $/ \mathrm{ml}$ for antagonists and $1 \times 10^{5}$ con$\mathrm{idia} / \mathrm{ml}$ for B. aclada.

Bioassay on dead leaves. Onion leaf segments for use in bioassays were washed thoroughly with tap water to remove soluble nutrients and subsequently blotted dry with sterile filter paper (21). Six leaf segments were placed in each of a series of moist chambers. Each chamber consisted of a sterile plastic petri dish $(90 \mathrm{~mm}$ in diameter) containing two sterile filter papers ( $80 \mathrm{~mm}$ in diameter) and $1 \mathrm{ml}$ of sterile tap water. The experiment was carried out in a completely randomized design with five replications (petri dish) with 10 treatments. The treatments were each of the four antagonists applied alone or in combination with B. aclada and B. aclada applied alone. In another control treatment, no fungi were applied to the leaf segments. Conidial suspensions of B. aclada or water plus surfactant were sprayed onto the leaf segments in the moist chambers, and the segments were incubated at $18^{\circ} \mathrm{C}$ for $24 \mathrm{~h}$. Immediately after the incubation periods, spore suspensions of antagonists or water plus surfactant were sprayed onto the segments. Thereafter, leaves were further incubated at $18^{\circ} \mathrm{C}$ in the dark.

For light and electron microscopy observations, samples were taken 6 days after application of the antagonists, since preliminary work had established this time period to be optimal. Leaf pieces $(2 \times 2 \mathrm{~mm})$ were cut from the central part of two randomly selected leaf segments of each replication of each treatment and were fixed and stored in glutaraldehyde (3\%, vol/vol) in $0.1 \mathrm{M}$ sodium cacodylate at $\mathrm{pH}$ 7.2. Samples from same treatments were bulked.

Eight days after antagonists had been applied, the leaf area covered with conidiophores of B. aclada was estimated using classes from 0 to 5 that represented, respectively, $0 \%, 1$ to $5 \%,>5$ to $25 \%,>25$ to $50 \%,>50$ to $75 \%$, and $>75$ to $100 \%$ of the leaf surface covered with conidiophores of the pathogen (21). From the number of leaf segments $(n)$ of each class (0 to 5) a sporulation index (SI) ranging from 0 to 100 was calculated for each replication (petri dish) consisting of four leaf segments ( $\mathrm{SI}=\left(0 \times n_{0}+5 \times\right.$ $\left.\left.n_{1}+25 \times n_{2}+50 \times n_{3}+75 \times n_{4}+100 \times n_{5}\right) / 4\right)$.

Assay on agar. Petri dishes containing $15 \mathrm{ml}$ of malt extract agar (10 $\mathrm{g}$ of malt extract, $15 \mathrm{~g}$ of agar, and 1,000 $\mathrm{ml}$ of tap water) were inoculated in four replicates with $5-\mathrm{mm}$ agar discs with mycelium of B. aclada or $U$. atrum that had been obtained from the margins of young colonies of the fungi grown on the same medium. Petri dishes were inoculated with one agar disc, two discs of the same fungus, or two discs of different fungi. The distance between two discs was $50 \mathrm{~mm}$. Plates were incubated at $18^{\circ} \mathrm{C}$ for 7 days. After 7 days, agar with mycelium was covered with a 1-mm layer of agarose (3\%) (E. van Balen, personal communication). Small pieces of agarose-covered agar with mycelium were cut from the margins of colonies. From plates with two colonies, samples were taken at the margins of both colonies where they had first contact. Samples were fixed and stored in glutaraldehyde $(3 \%, \mathrm{vol} / \mathrm{vol})$ in $0.1 \mathrm{M}$ sodium cacodylate at $\mathrm{pH} 7.2$.
Light and electron microscopy. Both leaf and agar samples were postfixed in $1 \%$ osmium tetroxide in $0.1 \mathrm{M}$ sodium cacodylate buffer at $4^{\circ} \mathrm{C}$ for $1 \mathrm{~h}$, before being dehydrated in an ethanol series and embedded in Epon 812. Sections $(0.7 \mu \mathrm{m})$ of leaf tissues were cut and mounted on glass slides prior to being stained with toluidine blue $(0.96 \mathrm{mg} / \mathrm{ml}$ of water $)$ or methylene blue $(10$ $\mathrm{mg} / \mathrm{ml}$ of water) and examined by light microscopy. Ultrathin sections $(0.1 \mu \mathrm{m})$ of leaf and agar samples were stained for transmission electron microscopy (TEM) with uranyl acetate and lead citrate prior to being examined, using a JEOL 1200 EX electron microscope (J. B. Em. Services, Montreal, Quebec, Canada) at an accelerating voltage of $80 \mathrm{kV}$. For each treatment of bulked samples, a minimum of three samples were cut into serial sections and examined under both light microscopy and TEM. Unless otherwise stated, reported observations were representative of all samples.

\section{RESULTS}

Bioassay. Under the constant humid conditions, all four antagonists efficiently suppressed the sporulation of B. aclada as in earlier experiments (21). The sporulation index for B. aclada was 41.8 (with a standard deviation of 5.8) when the pathogen had been sprayed alone. On leaf segments treated with B. aclada, no sporulation of B. aclada was observed when $G$. catenulatum or $C$. globosum had been applied, and the sporulation index was 0.8 and 0.3 for leaf segments treated with $A$. pullulans or $U$. atrum, respectively. $B$. aclada was not observed on leaf segments that had been treated with antagonists without $B$. aclada. Growth of all antagonists, resulting in sporulation of $G$. catenulatum and $U$. atrum and blastospore formation of $A$. pullulans, could be observed on the leaf segments whether or not treated with the pathogen. No fungal development was observed on leaves that had not been inoculated with any of the fungal suspensions.

Agar plate assay. Colonies of B. aclada or $U$. atrum grown alone showed a regular radial growth. When two colonies of the same fungus had been inoculated on a petri dish, colonies were slightly flattened where growing towards each other. Similar colony shapes were observed when $U$. atrum and B. aclada were grown in combination on the same petri dishes. There were no distinct inhibition zones between colonies of the same or the two different fungi. However, the colonies did not seem to grow into each other during the 7 days of the experiment.

Light microscopy. Colonization of dead onion leaves. Despite the fact that tissues and cells of irradiated dead onion leaves were quite disorganized, it was possible to observe a differential pattern of colonization among the five fungi 6 days after their inoculation. For instance, in all samples examined, B. aclada was found throughout the leaf section including the vascular tissue (Fig. 1A, arrowhead). In the same manner, $U$. atrum was found to be a very aggressive colonizer of onion leaves and was consistently observed in dense concentrations throughout the leaf tissues (Fig. 1B).

On the other hand, both $C$. globosum and, to an extent, $G$. catenulatum appeared to be confined primarily on the outer portion of the leaf surface (Fig. 2A). In all examined samples, $C$. globosum appeared less dense than B. aclada or U. atrum. G. catenulatum was found occasionally, although in low concentrations, in the parenchymal tissues and around the veins (data not shown). A. pullulans was characteristically concentrated in the leaf stomata (or between epidermal cells) (Fig. 2B and C), with a few fungal propagules being randomly dispersed underneath the epidermal cells (Fig. 2B and C, arrow).

Interactions between $\mathrm{B}$. aclada and the fungal antagonists. Of the four interactions, it was nearly impossible to generate salient information under light microscopy, because of the difficulty of precisely differentiating the fungi. In the case of Botrytis-Gliocladium, differences in mycelium diameter between the two species made it somewhat easier to separate them. From all samples 
studied, it was obvious that $B$. aclada was unable to colonize onion leaves to the extent observed in control treatments (Fig. 1A) when competing against $G$. catenulatum (Fig. 3A). In some instances, cells of B. aclada appeared dead, as evident by their lack of reaction with methylene blue (Fig. 3A, arrow).

For the Botrytis-Ulocladium interaction, abundant colonization and sporulation by the antagonist suggested that $U$. atrum had completely saturated the substrate (Fig. 3B). The antagonist was as abundant as in the controls (Fig. 1B), with the distinction that more spores were consistently observed on the leaf surface (Fig. 3B). In this situation, typical dictyospores of $U$. atrum covering the leaf surface (Fig. 3B, arrowheads) made it easy to identify the antagonist. In the numerous samples studied, it was impossible to confirm conclusively the presence of $B$. aclada under light microscopy.
Transmission electron microscopy. Botrytis-Gliocladium. Ultrastructural observations of dead onion leaves inoculated with $B$. aclada showed that fungal cells were of regular shape and contained a dense cytoplasm (Fig. 4A). Typical organelles such as nuclei and mitochondria were clearly visible, and the cells were surrounded by a thick fibrillar mucilage. By comparison, $G$. catenulatum cells were characteristically smaller than those of the pathogen (thus, confirming light microscopy observations) and were covered by a thin and irregular mucilage (Fig. 4B). Their cytoplasm was regular and contained a few large, electron-dense lipid bodies.

In the instances in which it was possible to observe both fungi in close vicinity, cells of $B$. aclada had lost all turgor pressure and were typically devoid of cytoplasmic content (Fig. 4C). They were reduced to empty shells shaped according to the presence of $G$.
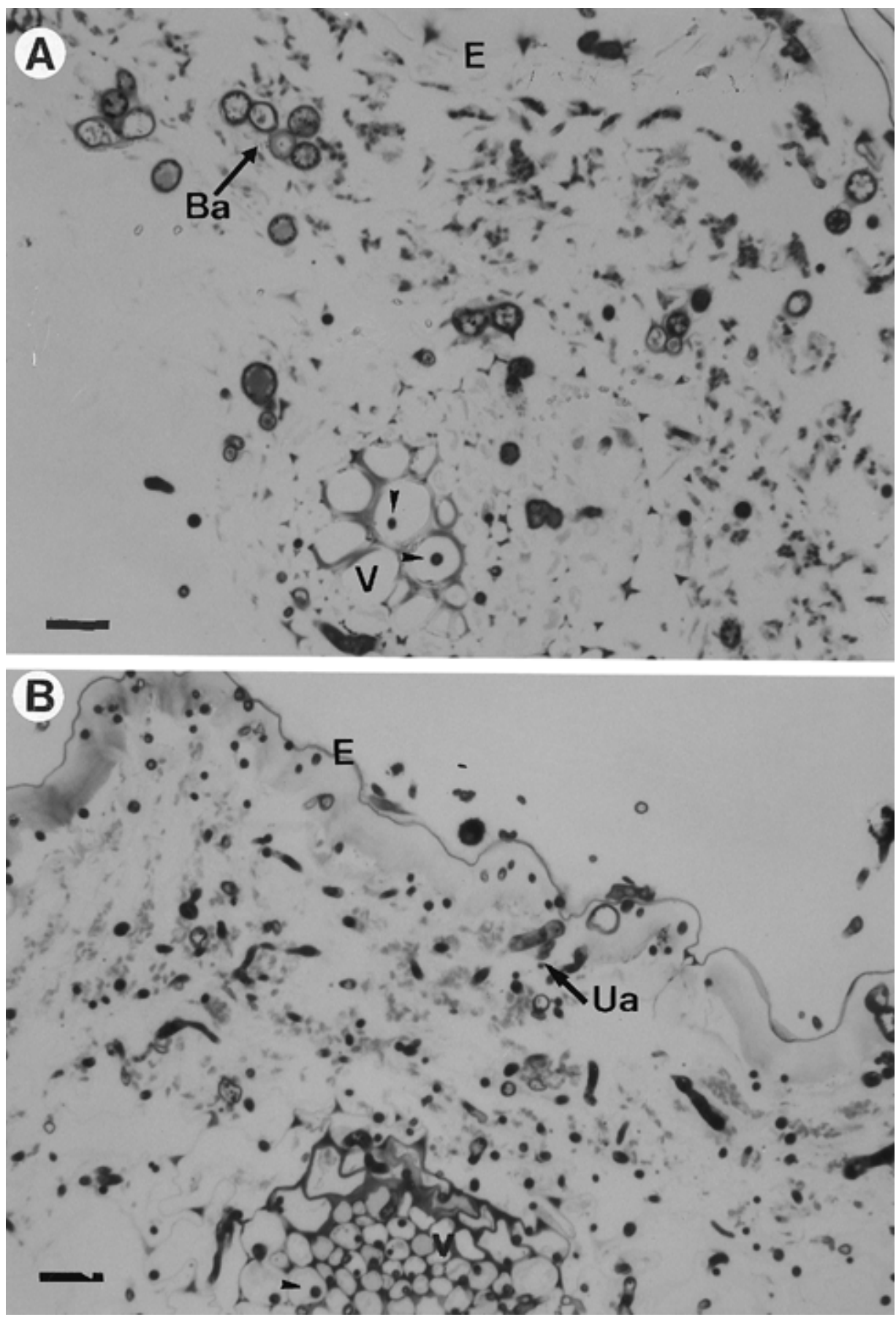

Fig. 1. Light micrographs of cross sections of dead onion (Allium cepa cv. Hyton) leaves 6 days after being inoculated with A, Botrytis aclada (Ba) and B, Ulocladium atrum (Ua). Bar $=25 \mu \mathrm{m}$. A, Cells of Ba can be found throughout the leaf tissues (arrows) from the epidermis (E) to the leaf vein (V). Note the presence of Ba within vein cells (arrowheads). B, Ua is present within the tissues in equal density from the epidermis (E) through the vein (V) cells (arrowhead). 
catenulatum hyphae. The cell wall of the pathogen was thicker compared with controls (Fig. 4A), but was otherwise unaltered, and no samples revealed the presence of the antagonist within $B$. aclada cells (Fig. 4C).

Botrytis-Chaetomium. In dead onion leaves inoculated with $C$. globosum alone, cross sections of fungal cells revealed a dense and uniform cytoplasm with a dark, lateral lipid body that sometimes covered most of the section (Fig. 5A). Leaf cell walls adjacent to fungal propagules were either degraded or characterized by a loose fibrillar appearance, suggestive of cellulolytic activity by the antagonist.

In the samples inoculated with both the pathogen and the antagonist, simultaneous presence of both fungi was rarely observed under TEM. In longitudinal sections, lipid bodies of $C$. globosum were quite numerous and distinctive, making it easy to identify the antagonist (Fig. 5B). Based on our observations, C. globosum was predominant over $B$. aclada within all treated leaf tissues. In a few instances, dead fungal cells completely devoid of their cytoplasm, appearing as empty hyphal shells, were observed in proximity to C. globosum (Fig. 5B and C). However, because of the advanced stage of degradation of these former cells, it was impossible to confirm whether they belonged to B. aclada.

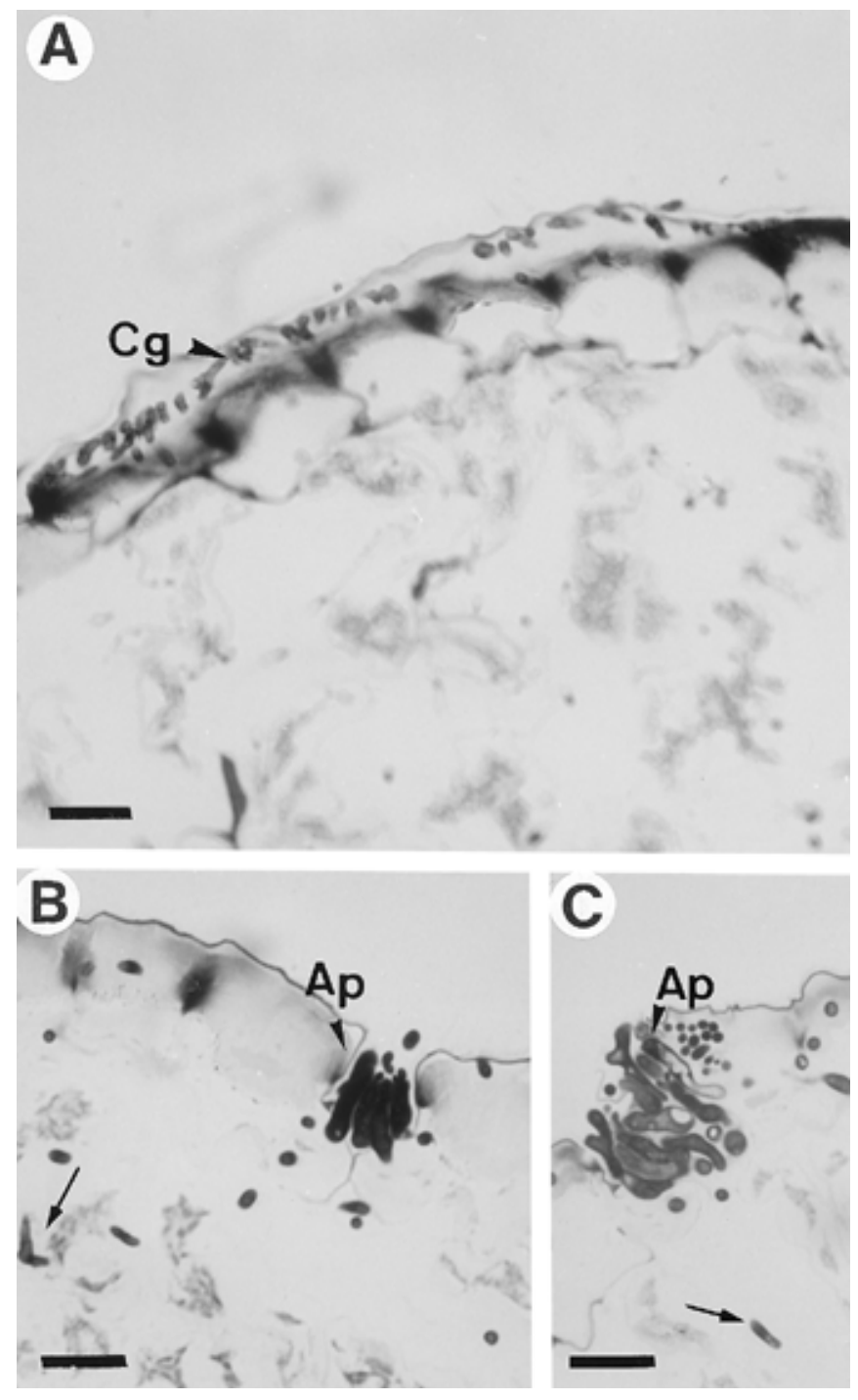

Fig. 2. Light micrographs of cross sections of dead onion (Allium cepa cv. Hyton) leaves 6 days after being inoculated with A, Chaetomium globosum $(\mathrm{Cg})$ and $\mathbf{B}$ and $\mathbf{C}$, Aureobasidium pullulans (Ap). Bar $=25 \mu \mathrm{m}$. A, Cg cells are typically concentrated on the leaf surface. $\mathbf{B}$ and $\mathbf{C}$, Characteristic clustering of Ap cells in leaf stomata. A few cells can be found below the epidermis around the clusters (arrows).
Botrytis-Aureobasidium. In dead onion leaves inoculated with A. pullulans, cells of the antagonist were typically found in clusters (Fig. 6A) as observed under light microscopy (Fig. 2B). They were characterized by a very dense cytoplasm and the presence of dark lipid bodies.

Close contact between B. aclada and A. pullulans cells revealed that the pathogen was affected by the presence of the antagonist (Fig. 6B). In these observations, cells of B. aclada had lost their integrity, and the cytoplasmic content of damaged cells had retracted away radially from the cells of $A$. pullulans. At the point of direct contact between the pathogen and the antagonist cells, the

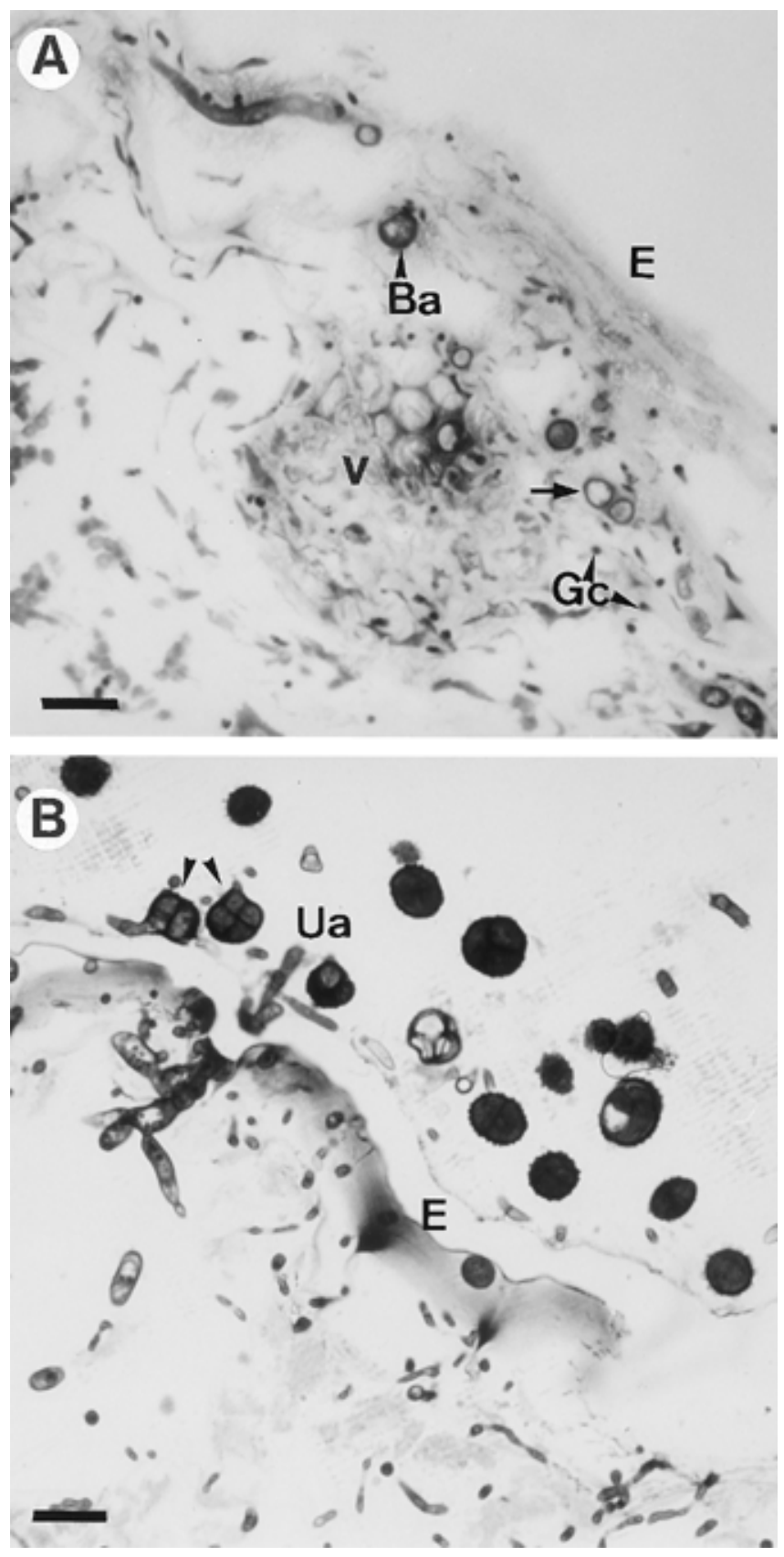

Fig. 3. Light micrographs of cross sections of dead onion (Allium cepa cv. Hyton) leaves inoculated with Botrytis aclada (Ba) $24 \mathrm{~h}$ prior to being inoculated with $\mathbf{A}$, Gliocladium catenulatum $(\mathrm{Gc})$ and $\mathbf{B}$, Ulocladium atrum (Ua). A, Ba and Gc cells together in dead onion tissues 6 days after application of the antagonist. Cells of $\mathrm{Ba}$ are considerably less dense than in samples in which it is inoculated alone (Fig. 1). Note the presence of empty Ba cells (arrow). Bar $=25 \mu \mathrm{m}$. B, Abundant Ua propagules under and above the epidermis. Note the formation and germination of typical conidia (dictyospores; arrowheads) of Ua on leaf surface 6 days after inoculation. No conclusive presence of $\mathrm{Ba}$. $\mathrm{Bar}=10 \mu \mathrm{m}$. $\mathrm{E}=$ epidermis; $\mathrm{V}=$ vein. 
cell wall of B. aclada had lost some of its definition and appeared distended and fibrillar (Fig. 6B, open arrow).

Botrytis-Ulocladium. In samples of dead onion leaves inoculated with $U$. atrum alone, the fungus was observed easily within tissues. Its cells were characterized by a granular cytoplasm containing several large lipid bodies of variable electron density; its cell wall was covered by a regular hairy mucilage, making it easy to discriminate from the cells of B. aclada (Fig. 7A). The fungus

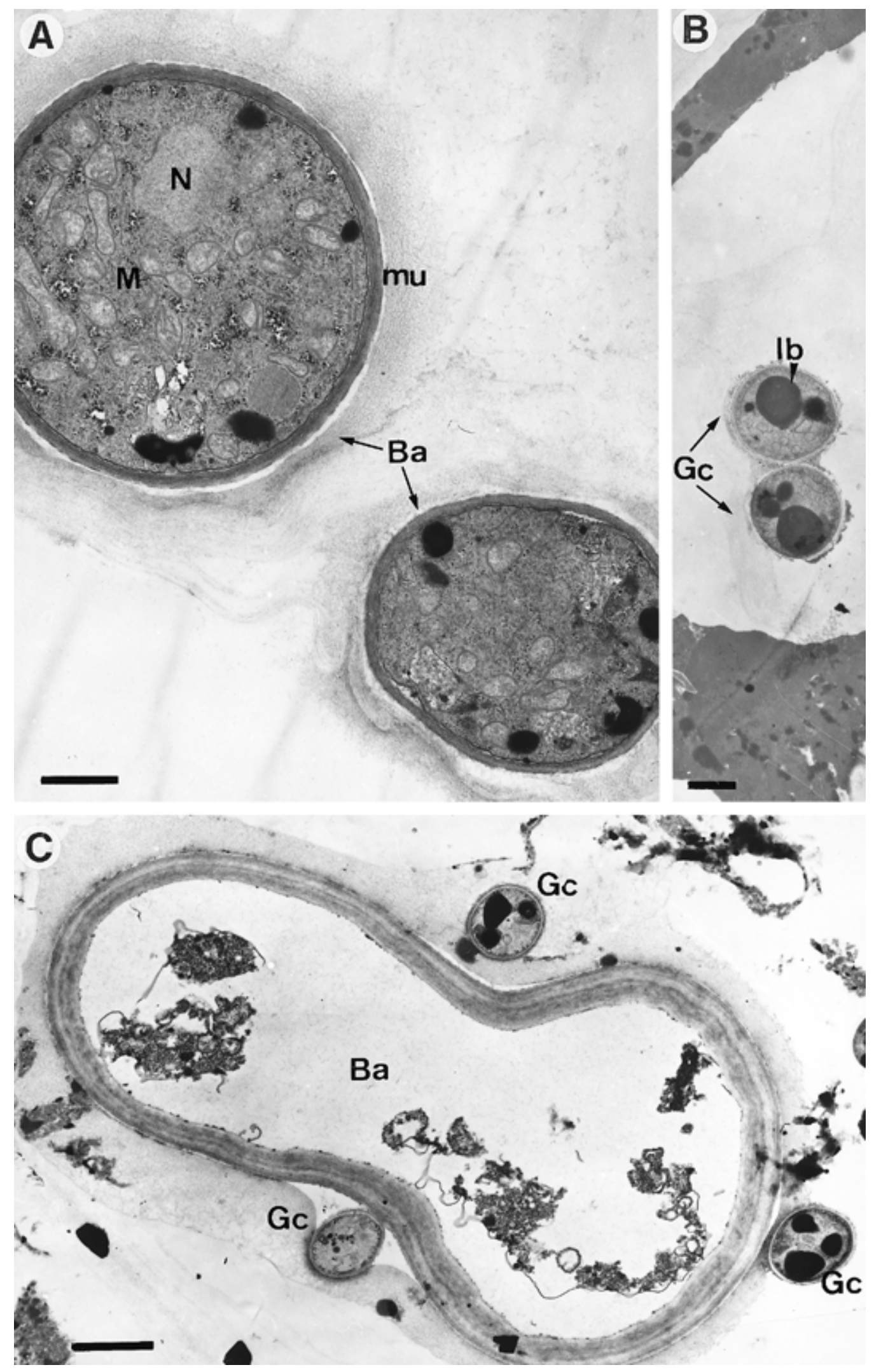

Fig. 4. Transmission electron micrographs of $\mathbf{A}$, Botrytis aclada (Ba) cells; $\mathbf{B}$, Gliocladium catenulatum $(\mathrm{Gc})$ cells; and $\mathbf{C}$, the interaction between Ba and Gc cells in dead onion (Allium cepa cv. Hyton) leaf tissues. A, Ba cells surrounded by a thick fibrillar mucilage (mu) and characterized by a dense cytoplasm filled with distinct organelles such as a nucleus $(\mathrm{N})$ and mitochondria $(\mathrm{M})$. Bar $=1 \mu \mathrm{m}$. B, Cells of Gc showing typical large lipid bodies (lb) and surrounded by a thin and irregular mucilage. $\mathrm{Bar}=1 \mu \mathrm{m}$. C, A dead cell of Ba surrounded by three cells of Gc. External pressure by Gc induces wall deformation. Note thickness of the cell wall of Ba. Bar $=2 \mu \mathrm{m}$. 
seemed to colonize all dead leaf tissues, and it was capable of degrading the plant cell walls (Fig. 7A, arrowhead). In the numerous samples observed, it was impossible to obtain conclusive evidence of the presence of B. aclada when both fungi were inoculated onto onion leaves (Fig. 7B). On the other hand, U. atrum was always conspicuously present and degraded the cell walls of onion leaves.

Because of the inability to observe interactions in planta between $B$. aclada and $U$. atrum, in vitro confrontations were stud- ied in an attempt to understand the basis of the antagonistic activity of $U$. atrum. In control samples, as observed in the bioassay, neither B. aclada nor $U$. atrum were markedly altered by a selfconfrontation. Confrontations between the pathogen and the antagonist failed to show typical reactions of parasitism or antibiosis in the bioassay. On the other hand, TEM observations at the zone of contact revealed that fungal cells from both fungi showed varying degrees of alteration at the immediate zone of contact.

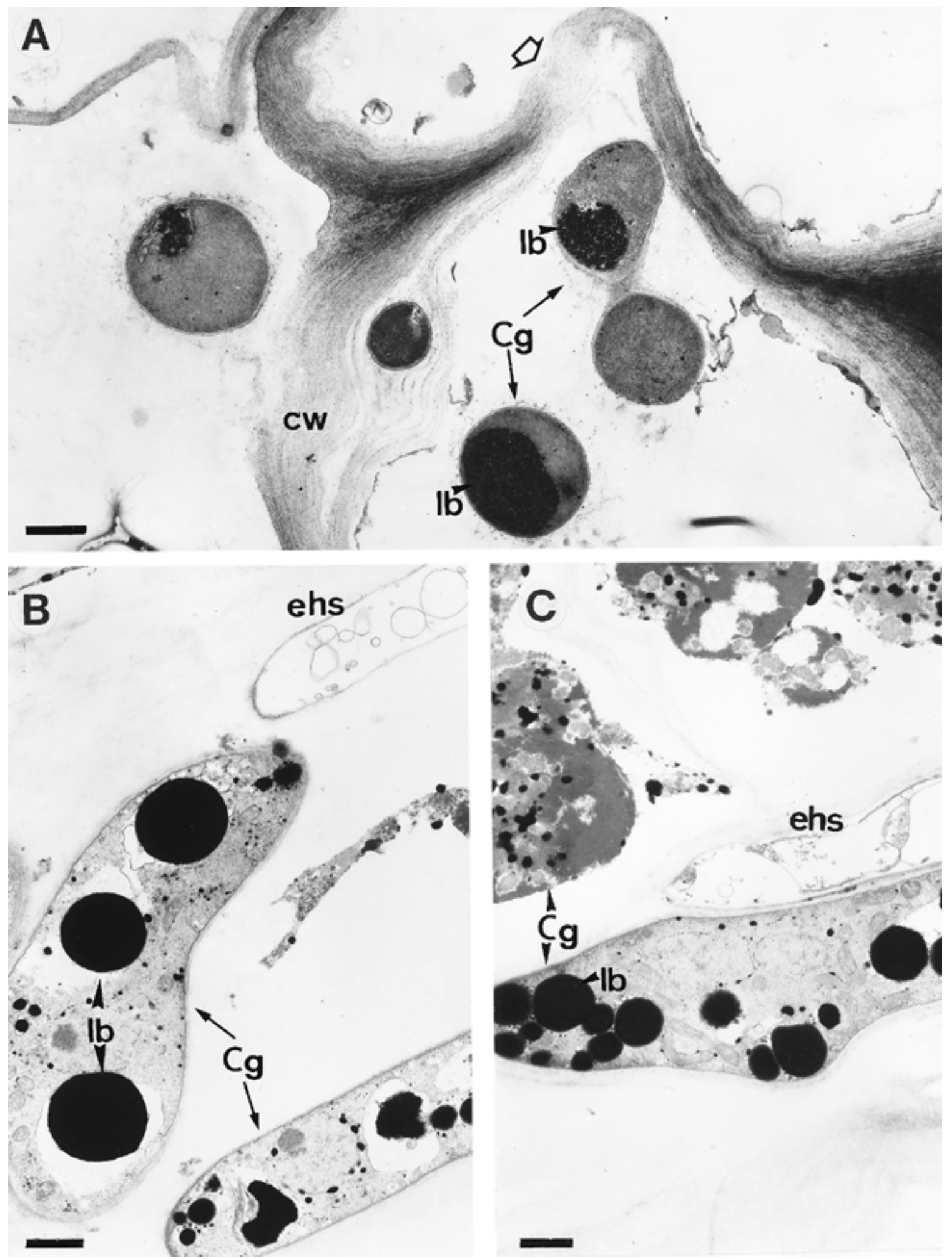

Fig. 5. Transmission electron micrographs of A, Chaetomium globosum $(\mathrm{Cg})$ cells in dead onion (Allium cepa cv. Hyton) leaf tissues and $\mathbf{B}$ and $\mathbf{C}$, Cg cells and dead fungal cells 6 days after inoculation of the antagonist on dead onion leaf tissues that had been inoculated with Botrytis aclada. Bar $=1 \mu \mathrm{m}$. A, Cg is characterized by a dense cytoplasm and the presence of large and electron dense lipid bodies (lb). The plant cell wall (cw) is highly degraded and near complete disruption in certain areas (open arrow). B and C, Presence of empty hyphal shells (ehs) in proximity of Cg cells. Note typical lb of the antagonist. 
This ranged from detached plasmalemma to slight disorganization of the cytoplasm (Fig. 7C and D). These alterations subsided gradually away from the contact zone, and neither fungus appeared to overcome the other.

\section{DISCUSSION}

All four antagonists tested in this study suppressed sporulation of B. aclada almost completely in the bioassay. This agrees with earlier results obtained by Köhl et al. (21) that had shown the relative biocontrol potential of $A$. pullulans, $C$. globosum, $G$. catenulatum, and $U$. atrum. However, microscopic observations of the interactions have highlighted some important differences among the four fungi in terms of their antagonistic activity against B. aclada. This information is of key importance in establishing the respective behavior of the antagonists and how this behavior can influence the eventual success of biocontrol of Botrytis spp.

Based on our light and electron microscopy studies, A. pullulans grew in a yeastlike manner. Clusters of cells, most probably blastospores, were formed on the leaf surface or inside stomata, whereas hyphae were rarely found inside the tissue. This can be explained by the limited formation of hyphae in solid media by this dimorphic fungus (1). Considering this colonization pattern, it
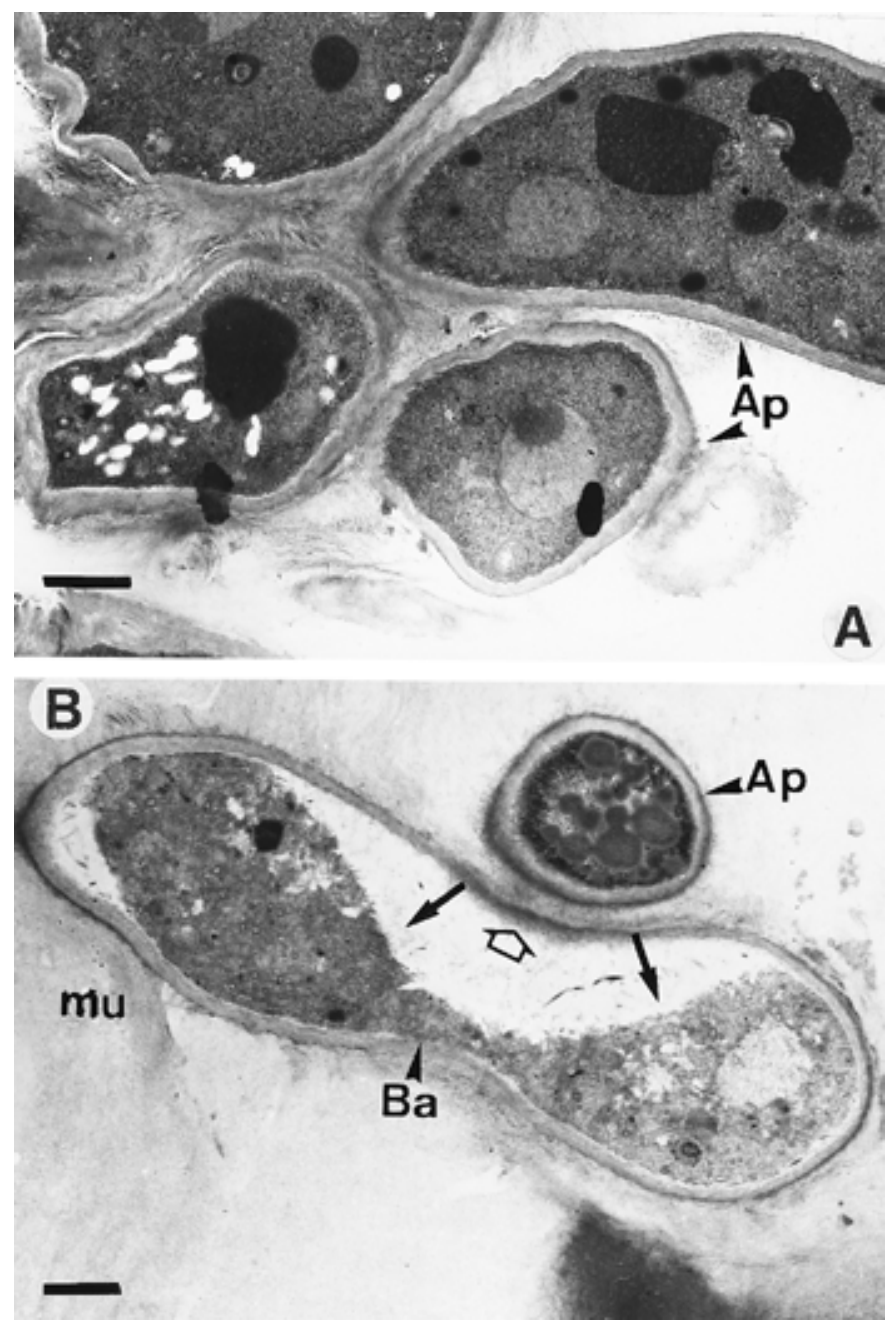

Fig. 6. Transmission electron micrographs of A, Aureobasidium pullulans (Ap) cells in dead onion (Allium cepa cv. Hyton) leaf tissues and B, Ap and Botrytis aclada $(\mathrm{Ba})$ cells in dead onion leaf tissues inoculated with both the pathogen and the antagonist. Samples were taken 6 days after inoculation with Ap. Bar $=1 \mu \mathrm{m}$. A, Cells of Ap are frequently found in clusters and characterized by a very dense cytoplasm. B, Interaction between $\mathrm{Ba}$ and Ap. Note Ba cytoplasm retracted radially from Ap (arrows). Note change in Ba cell wall definition and density at point of direct contact with Ap (open arrow). is unlikely that nutrient competition within the substrate would play a major role in antagonism, since the substrate would only be depleted locally at the site where colonies are formed. On the other hand, A. pullulans could be an efficient antagonist for the protection of leaf surfaces and man-made wounds, as previously reported $(11,13)$. The in vitro production of antibiotic compounds by $A$. pullulans has been described $(4,23)$. In the present work, in the rare instances in which close contact between $A$. pullulans and $B$. aclada was found, our observations appeared to support a chemical antibiosis by A. pullulans (Fig. 6B).

The colonization of dead onion tissues by $C$. globosum was poor, and its hyphae were mostly restricted to the leaf surface. However, the ultrastructural studies indicated that this antagonist, which is known for its strong cellulolytic activity (9), has the potential to degrade plant cell walls. C. globosum was previously found to be antagonistic against several plant pathogens such as Pythium ultimum (7) and Venturia inaequalis (17) and is known to produce two antifungal substances (7). The production of antibiotics by $C$. globosum may also explain its antagonistic activity against $B$. cinerea under certain field conditions, regardless of the presence of an actively growing population of the antagonist on the substrate (20). In our ultrastructural studies, highly disorganized fungal cells were associated with cells of C. globosum, whereas such dead cells were not found when the antagonist was grown alone. This would support the manifestation of in situ antibiotic activity by $C$. globosum. However, it was not possible to confirm whether these dead cells belonged to B. aclada, but it can be assumed, supported by the information given in literature and our observations, that the antagonist did induce cell death of $B$. aclada. Because of its limited colonization potential, it would appear that antibiosis, if not exclusively, is at least an important component of the biocontrol ability of $C$. globosum.

In previous experiments, $G$. catenulatum displayed strong antagonism against Botrytis spp. under continuously moist conditions favorable for fungal growth (21). Our studies revealed that G. catenulatum could colonize all parts of necrotic tissues, but that this colonization was not very extensive. Nevertheless, colonization of $B$. aclada was considerably reduced in the presence of the antagonist. Antibiosis was clearly one of the modes of action of $G$. catenulatum, based on cell reactions of $B$. aclada, which were typical of toxic activity such as cytoplasm degradation and loss of turgor pressure $(16,28)$. No clear signs of hyperparasitism such as cell wall degradation at sites of contact between hyphae of the two organisms were found. While no information is given in the literature about the mode of action of $G$. catenulatum, such information abounds about other species of Gliocladium and the closely related Trichoderma spp. (6,24). For instance, G. virens has been described as an antibiotic producer, and its activity against Pythium ultimum and Rhizoctonia solani is strongly related to the antibiotics it produces (18). Di Pietro et al. (8) suggested that enzymes such as beta-glucanases provided a synergistic effect with the toxins, but evidence of hydrolytic activity of $G$. virens in situ has never been reported. In addition, while some Trichoderma spp. have been shown to degrade their host cells enzymatically, it is well established that they produce a number of antibiotic substances (14). In the chronological events associated with the antagonism of Trichoderma harzianum against $B$. cine$r e a$, Bélanger et al. (2) showed that antibiosis preceded penetration and suggested that the enzymatic cell wall degradation was more a saprophytic action than the cause of death in $B$. cinerea.

In the case of $U$. atrum, there are no previous reports on microscopic studies of the colonization of necrotic plant tissue or possible mechanisms of antagonism by this fungus. Among the four antagonists in our study, U. atrum expressed the best colonization potential on dead onion leaves and also the strongest antagonism on leaves that had been exposed to field conditions in a previous study (20). This antagonist also showed a high ecological competence for the habitat of above-ground necrotic plant tissues and 
was able to germinate and colonize the substrate under various environmental conditions in the presence of Botrytis spp. and other naturally occurring saprophytic fungi (20). This ability to colonize necrotic tissues at least under high humidity, a prerequisite for strong competitors, was confirmed in this work. Indeed, $U$. atrum mycelium was found to be present and distributed throughout necrotic leaf tissues, and B. aclada seemed to be completely excluded from that niche. Ultrastructural studies showed that $U$. atrum degraded plant cell walls actively so that it could grow through the dead plant cells walls. Because B. aclada could not be detected in necrotic leaf tissues in the presence of $U$. atrum, it was not possible to determine if antibiosis or parasitism complemented its competition for substrate in onion leaves. However, when the interaction between both fungi was studied on agar, there were no obvious signs of hyperparasitism or antibiosis, as the fungi seemed unaltered. This would indicate that $U$. atrum relies exclusively on competition for gaining access to its ecological niche over $B$. aclada. The ability to colonize and utilize necrotic tissues rapidly may enable $U$. atrum to exclude competitors from the substrate without any other antagonistic interaction. These findings may have practical implications for the proper timing of application of the antagonist and for predicting its limitations. Most efficient control of substrate colonization and subsequent sporulation of the pathogen may be achieved on freshly senesced tissues or in freshly pathogen-induced lesions in which mycelium of the pathogen is not established in high density to allow profuse sporulation. Since the antagonist seems to lack the ability to kill fungal cells by toxins or hyperparasitism, a curative application of $U$. atrum would
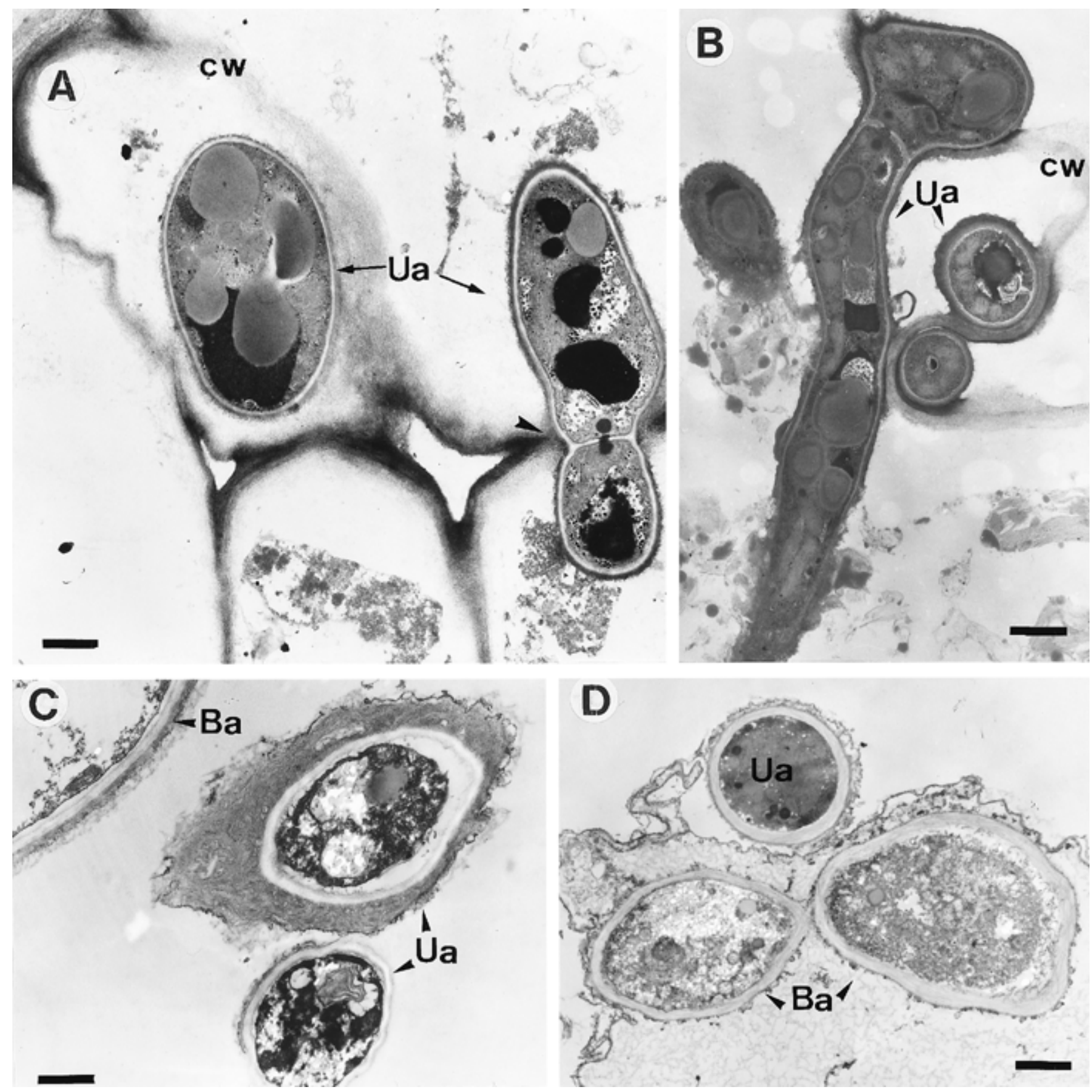

Fig. 7. Transmission electron micrographs of A, Ulocladium atrum (Ua) cells in dead onion (Allium cepa cv. Hyton) leaf tissues; B, Ua cells in dead onion leaf tissues inoculated with both Botrytis aclada $(\mathrm{Ba})$ and $\mathrm{Ua}$; and $\mathbf{C}$ and $\mathbf{D}, \mathrm{Ba}$ and Ua cells taken at the meeting point of two colonies growing on agar plates. Leaf samples were taken 6 days after inoculation with Ua. Bar $=1 \mu \mathrm{m}$. A, Plant cell walls (cw) of onion leaves are highly degraded in the presence of Ua. Note the passage of an Ua cell through the plant cell wall (arrowhead). B, In the interaction B. aclada-U. atrum, only cells of the antagonist are observed within the plant tissues. Note the degradation of the plant cw. $\mathbf{C}$ and $\mathbf{D}$, Cells of both fungi show varying degrees of alteration when grown in confrontation on agar medium. 
be unlikely to reduce the pathogen population already established in high densities. However, nutrient competition resulting in reduced spore yields of the pathogen may also play a role when $U$. atrum colonizes substrates where Botrytis mycelium is already established. Further research is needed to study how the initial density of mycelium of Botrytis spp. and $U$. atrum affect subsequent substrate colonization by both fungi.

The exploitation of biological control agents with mechanisms that are mainly based on competition for nutrients and space can provide distinct advantages against necrotrophic plant pathogens that rely on their saprophytic phase for establishing a critical base population. Firstly, the antagonistic interaction is not specific for certain pathogen-antagonist relationships. For example, U. atrum is known to compete with and suppress sporulation of a range of Botrytis spp. and other saprophytic fungi such as Cladosporium spp. and Alternaria spp. (20). Secondly, there is no strict necessity for the simultaneous presence of antagonist and pathogen. The antagonist can utilize the limited amounts of nutrients in necrotic tissues long before the pathogen arrives and, thus, restricts access to the substrate. Organisms acting strictly by hyperparasitism depend on the presence of the pathogen for activity. In addition, the process can be relatively slow and often times only activated when the pathogen itself is under stress (2). In the case of antibiosis, while efficient against biotrophs such as powdery mildews (3), it is also subject to a precise timing of release against necrotrophs, because antibiotics produced early before arrival of the pathogen may be degraded or may be adsorbed to cell surfaces $(5,10)$. Thirdly, it is unlikely that resistance against competition will be developed by Botrytis populations. This point is of particular significance considering the ability of $B$. cinerea to develop resistance against fungicides (15). This phenomenon was also reported against two antibiotics produced by Bacillus subtilis after nine subsequent crops of Astilbe had been sprayed with the antagonist (22).

In conclusion, our study is the first to report ultrastructural observations of a fungal pathogen and potential antagonists in situ as they colonize and interact on their natural substrate, dead onion leaves. These ultrastructural observations have provided insight into the mode of action of these antagonists and have highlighted the importance of understanding such phenomena in the selection and development of biocontrol agents.

\section{ACKNOWLEDGMENTS}

We thank C. Labbé and W. M. L. Molhoek for technical assistance.

\section{LITERATURE CITED}

1. Andrews, J. H., Harris, R. F., Spear, R. N., and Nordheim, E. V. 1994. Morphogenesis and adhesion of Aureobasidium pullulans. Can. J. Microbiol. 40:6-17.

2. Bélanger, R. R., Dufour, N., Caron, J., and Benhamou, N. 1995. Chronological events associated with the antagonistic properties of Trichoderma harzianum against Botrytis cinerea: Indirect evidence for sequential role of antibiosis and parasitism. Biocontrol Sci. Technol. 5:41-53.

3. Bélanger, R. R., Labbé, C., and Jarvis, W. R. 1994. Commercial-scale control of rose powdery mildew with a fungal antagonist. Plant Dis. 78: 420-424.

4. Bhatt, D. D., and Vaughan, E. K. 1963. Inter-relationships among fungi associated with strawberries in Oregon. Phytopathology 53:217-220.

5. Boudreau, M. A., and Andrews, J. H. 1987. Factors influencing antagonism of Chaetomium globosum to Venturia inaequalis: A case study in failed biocontrol. Phytopathology 77:1470-1475.
6. Chet, I. 1987. Trichoderma-Application, mode of action and potential as a biocontrol agent of soilborne plant pathogenic fungi. Pages 137-160 in: Innovative Approaches to Plant Disease Control. I. Chet, ed. John Wiley \& Sons, New York.

7. Di Pietro, A., Gut-Rella, M., Pachlatko, J. P., and Schwinn, F. J. 1992. Role of antibiotics produced by Chaetomium globosum in biocontrol of Pythium ultimum, a causal agent of damping-off. Phytopathology 82:131-135.

8. Di Pietro, A., Lorito, M., Hayes, C. K., Broadway, R. M., and Harman, G. E. 1993. Endochitinase from Gliocladium virens: Isolation, characterization, and synergistic antifungal activity in combination with gliotoxin. Phytopathology 83:308-313.

9. Domsch, K. H., Gams, W., and Anderson, T. H. 1990. Compendium of Soil Fungi. Academic Press, London.

10. Edwards, S. G., and Seddon, E. 1992. Bacillus brevis as a biocontrol agent against Botrytis cinerea on protected Chinese cabbage. Pages $267-$ 271 in: Recent Advances in Botrytis Research. K. Verhoeff, N. E. Malathrakis, and B. Williamson, eds. Pudoc Scientific Publishers, Wageningen, the Netherlands.

11. Falconi, C. J., and Mendgen, K. 1994. Epiphytic fungi on apple leaves and their value for control of the postharvest pathogens Botrytis cinerea, Monilinia fructigena and Penicillium expansum. Z. Pflanzenkr. Pflanzenschutz 101:38-47.

12. Fokkema, N. J. 1993. Opportunities and problems of control of foliar pathogens with micro-organisms. Pestic. Sci. 37:411-416.

13. Fokkema, N. J., and Lorbeer, J. W. 1974. Interactions between Alternaria porri and the saprophytic mycoflora of onion leaves. Phytopathology 64:1128-1133.

14. Ghisalberti, E. L., and Sivasithamparam, K. 1991. Antifungal antibiotics produced by Trichoderma spp. Soil Biol. Biochem. 23:1011-1020.

15. Gullino, M. L. 1992. Chemical control of Botrytis spp. Pages 217-222 in: Recent Advances in Botrytis Research. K. Verhoeff, N. E. Malathrakis, and B. Williamson, eds. Pudoc Scientific Publishers, Wageningen, the Netherlands.

16. Hajlaoui, M. R., Traquair, J. A., Jarvis, W. R., and Bélanger, R. R. 1994. Antifungal activity of extracellular metabolites produced by Sporothrix flocculosa. Biocontrol Sci. Technol. 4:229-237.

17. Heye, C. C., and Andrews, J. H. 1983. Antagonism of Athelia bombacina and Chaetomium globosum to the apple scab pathogen, Venturia inaequalis. Phytopathology 73:650-654.

18. Howell, C. R., and Stipanovic, R. D. 1995. Mechanisms in the biocontrol of Rhizoctonia solani-induced cotton seedling disease by Gliocladium virens: Antibiosis. Phytopathology 85:469-472.

19. Köhl, J., Molhoek, W. M. L., van der Plas, C. H., and Fokkema, N. J. 1995. Suppression of sporulation of Botrytis spp. as a valid biocontrol strategy. Eur. J. Plant Pathol. 101:251-259.

20. Köhl, J., Molhoek, W. M. L., van der Plas, C. H., and Fokkema, N. J. 1995. Effect of Ulocladium atrum and other antagonists on sporulation of Botrytis cinerea on dead lily leaves exposed to field conditions. Phytopathology 85:393-401.

21. Köhl, J., van der Plas, C. H., Molhoek, W. M. L., and Fokkema, N. J. 1995. Effect of interrupted leaf wetness periods on suppression of sporulation of Botrytis allii and B. cinerea by antagonists on dead onion leaves. Eur. J. Plant Pathol. 101:627-637.

22. Li, H., and Leifert, C. 1994. Development of resistance in Botryotinia fuckeliana (de Bary) Whetzel against the biological control agent Bacillus subtilis CL27. Z. Pflanzenkr. Pflanzenschutz 101:414-418.

23. McCormack, P. J., Wildman, H. G., and Jeffries, P. 1994. Production of antibacterial compounds by phylloplane-inhabiting yeasts and yeastlike fungi. Appl. Environ. Microbiol. 60:927-931.

24. Papavizas, G. C. 1985. Trichoderma and Gliocladium: Biology, ecology, and potential for biocontrol. Annu. Rev. Phytopathol. 23:23-54.

25. Pfender, W. F. 1988. Suppression of ascocarp formation in Pyrenophora tritici-repentis by Limonomyces roseipellis, a basidiomycete from reduced-tillage wheat straw. Phytopathology 78:1254-1258.

26. Pfender, W. F., Zhang, W., and Nus, A. 1993. Biological control to reduce inoculum of the tan spot pathogen Pyrenophora tritici-repentis in surface-borne residues of wheat fields. Phytopathology 83:371-375.

27. Whipps, J. M. 1992. Status of biological disease control in horticulture. Biocontrol Sci. Technol. 2:3-24.

28. Yoder, O. C. 1980. Toxins in pathogenesis. Annu. Rev. Phytopathol. 18:103-129. 